\title{
An overview of the clinical use of ondansetron in preschool age children
}

\author{
Ira Todd Cohen \\ Department of Anesthesiology, \\ Children's National Medical Center, \\ George Washington University, \\ Washington, DC, USA
}

\begin{abstract}
The introduction of 5- $\mathrm{HT}_{3}$ receptor antagonist has revolutionized the prevention and treatment of nausea and vomiting in preschool aged children. These distressing symptoms, arising from multiple etiologies such as anesthesia, chemotherapy, and viral infection, are a major concern of patients and their families. Clinical research has demonstrated the antiemetic effectiveness of ondansetron in children. Although most of these studies focus primarily on preventing vomiting across the pediatric age group, they provide strong evidence for the use of ondansetron in preschool age children. For children at high risk, pediatric practice guidelines recommend ondansetron in conjunction with other antiemetics to achieve complete control of symptoms.
\end{abstract}

Keywords: ondansetron, children, preschool, nausea, vomiting, postoperative nausea and vomiting, chemotherapy, gastroenteritis

\section{Introduction}

Nausea and vomiting are frequently experienced in infancy and preschool age childhood (Iacono et al 2005). These distressing symptoms are associated with common childhood occurrences such as car travel and gastroenteritis as well as postoperative recovery and cancer-related interventions. Once considered an inconvenient but unavoidable outcome of anesthesia, surgery, chemotherapy and radiation, nausea and vomiting are now recognized as the number one concern of patients and their families (Eberhart et al 2002; Wisselo et al 2004; Lee 2005). Recent investigations have revealed that distress, discomfort, and disruption associated with nausea and vomiting are significant even in the youngest of patients (Khalil et al 2005; Holdsworth 2006). Increased awareness, availability of 5-hydroxytryptamine (5-HT3) receptor antagonists, and combined anti-emetic strategies should decrease the incidence of nausea and vomiting in this overlooked age group.

The 5-HT3 receptor antagonist ondansetron, first heralded by Lancet in 1987, was rapidly recognized as having broad applicability with significant benefits (Anonymous 1987). Initially studied in patients receiving cis-platinum, ondansetron was soon shown to be effective in preventing radiation- and chemotherapy-induced nausea and vomiting (Green et al 1989). By the early 1990s, it was documented that ondansetron decreased postoperative nausea and vomiting (PONV) in adults and children (Leeser and Lip 1991; Litman et al 1994). In placebo-controlled and comparative studies of patients undergoing various oncologic therapies and surgical procedures, ondansetron had consistently performed in the prevention and treatment of vomiting. Unlike traditional antiemetics, ondansetron was not associated with pronounced adverse reactions such as electrocardiograph abnormalities, somnolence, dysphoria, dystonia, and confusion. Due to its favorable therapeutic index, ondansetron has become the most frequently prescribed antiemetic. For young children and other patients who cannot swallow pills, 
ondansetron is also available in dissolving tablets and oral liquid formulations (Dupuis and Nathan 2003).

\section{Etiology}

Nausea and vomiting arises from multiple etiologies. Each involves a complex series of humoral and neurological interactions resulting in the stimulation of the vomiting center, a nucleus of cells in the medulla (Andrews and Hawthorn 1988). Neurotransmitters involved in this process include dopamine, acetylcholine, histamine, endorphins, serotonin, and neurokinin (NK1) (Pisters and Kris 1998). Receptors for these neurotransmitters are common in the vomiting center, chemoreceptor trigger zones (CTZ), and gastrointestinal (GI) tract. The vomiting center receives input from at least four sources: the CTZ, GI tract, vestibular apparatus, and cerebral cortex. The CTZ, which lie in the brain stem beneath the fourth ventricle, sense chemical abnormalities in the body and indirectly receive input from the vagus nerves. Distention and inflammation of the GI tract and other internal organs cause the release of emetogenic substances and stimulates the CTZ via the vagus. Vestibular apparatus plays a role in motion sickness while the cerebral cortex is instrumental in olfactory, emotional, and anticipatory nausea and vomiting. It is postulated that ondansetron and other 5-HT3 receptor antagonists exerts its antiemetic action both peripherally (vagus and sympathetic nerves) and centrally (CTZ and vomiting center) by blocking stimulation of serotonin receptors (Pisters and Kris 1998).

\section{Postoperative nausea and vomiting}

PONV, which is defined as early ( $0-6$ hours) and delayed (6-48 hours) has been extensively studied in children due to its frequency, predictability, and economic impact. It is postulated that the surgical and anesthesia-related etiology of PONV is multifactorial, arising from direct stimulation of the CTZ by anesthetic agents (ie, nitrous oxide, opioids, anticholinesterases, and volatile gases) indirect stimulation from vagal transmission secondary to surgical manipulation (Watcha and White 1992). Over 25 randomized control trials of ondansetron prophylaxis have been performed in infants and preschool aged children. In pediatric patients, PONV is the leading cause of delayed discharge and emergency readmission (Patel and Hannallah 1988; Gold et al 1989). These patients are $50 \%-75 \%$ more likely to develop PONV than their adult counter parts with an incidence of $34 \%-50 \%$ in school age children and $20 \%$ in preschool children (Cohen et al 1990). The highest incidence of PONV is associated with eye muscle surgery, tonsillectomy, adenoidectomy, orchidopexy, and hernia repair reported high as $88 \%, 70 \%$, $50 \%$, and 40\%, respectively (Lerman 1992; Watcha and White 1992). Recent studies have demonstrated that the occurrence of PONV in 1- and 2-year-olds is higher than previously documented (Khalil et al 2005). Risk factors for PONV in children are summarized in Table 1. Over the last three decades numerous antiemetic medications have been studied, including droperidol, metoclopramide, dimenhydrinate, promethazine, prochlorperazine, scopolamine, and corticosteroids but the greatest success has been documented with 5-HT3 receptor antagonists, in general, and ondansetron, in particular.

Most pediatric PONV clinical trials have focused on early PONV, grouped preschool age children with school aged children, and reported emesis, not nausea, as their determinant factor. These data do not allow for easy analysis of antiemetic response to ondansetron in younger children and antinausea response in children overall. Other study limitations include a focus on prevention as opposed to treatment, high risk procedures such as strabismus repair and adenotonsillectomy, and combined therapy evaluations. For ease of comparison, results of these studies are discussed in this chapter as the number needed to treat (NNT) within a confidence intervals of $95 \%$ (CI 95\%). NNT is the number of subjects required to be treated to result in one less patient having symptoms compared with those patients who received placebo. The smaller the NTT, the more effective is the medication. If not otherwise noted, NNT is reported for placebo-controlled studies.

Meta-analyses of studies examining PONV prophylaxis with ondansetron, 50-100 $\mu \mathrm{g} / \mathrm{kg}$ intravenously, found the NNT to be 3 (CI 95\% 2-5) for early PONV (Tramer et al 1997). In comparison, meta-analyses of early PONV prophylactic dexamethasone (following tonsillectomy), droperidol, and metoclopramide found the NNT to be approximately 4 (CI 95\% 2-6), 5 (CI 95\% 3-7), and 8 (CI 95\% 5-28), respectively (Steward et al 2002; Henzi et al 1999, 2000).

Table I Risk factors for postoperative nausea and vomiting in children

\begin{tabular}{ll}
\hline Surgery - type & Use of volatile anesthetics \\
Surgery - duration & Use of nitrous oxide \\
History of PONV & Use of opioids \\
History of motion sickness & Use of reversal agents \\
\hline
\end{tabular}

Adapted from Gan et al (2003).

Abbreviations: PONV, postoperative nausea and vomiting. 
In children, other available 5-HT3 receptor antagonists have similar treatment profiles compared with ondansetron (Gan 2005).

Adverse drug reactions with ondansetron use are reported as being equal to or less than that reported in control (placebo) groups (Culy et al 2001). Less than 1\% of children complain of headache or dizziness. Other reported adverse responses, which are rare but serious, include electrocardiography alteration involving sodium channels changes, central nervous changes such as dyskinesias, and elevated liver enzymes (Goodin and Cunningham 2002; Kovac 2002). In contrast, side-effects reported with metoclopramide such as headaches, high levels of sedation, and extrapyramidal symptoms occurred with statistically significant greater frequency (Domino et al 1999). Droperidol profile is less favorable secondary to more pronounced side-effects such as somnolence and a theoretical increased risk of cardiac arrhythmia in children.

\section{Chemotherapy-induced nausea and vomiting}

In patients of all ages, chemotherapy-induced nausea and vomiting (CINV) and radiation-induced nausea and vomiting (RINV) are sited as the most common fear and the leading cause of poor compliance (Coates et al 1983). The percentage of patients experiencing vomiting with specific chemotherapy agents ranges from greater than $90 \%$ with cisplatin $\left(>50 \mathrm{mg} / \mathrm{m}^{2}\right)$ to less than $10 \%$ with vincristine (Schnell 2003). High, moderate, and low risk emetogenic agents are presented in Table 2 .

CINV is classified as acute, delayed, and anticipatory with severity directly related to emetogenic potential of antioncologic therapy and efficacy of prevention and treatment
(Antonarakis and Hain 2005). Acute CINV, by definition, occurs within 24 hours after a chemotherapy dose. With modern antiemetic prophylaxis $76 \%-86 \%$ of children receiving a variety of emetogenic chemotherapy agents are emesis free (Foot and Hayes 1994; Kusnierczyk et al 2002). Delayed CINV occurs 24 hours or more after a chemotherapy dose and may persist for 5-7 days. The incidence, patterns, and risk factors in children are poorly understood but delayed CINV is more commonly associated with the use of cisplatin, carboplatin, and/or cyclophosphamide as well as vomiting during the acute phase (Dupuis and Nathan 2003). Anticipatory CINV occurs prior to the administration of chemotherapy and, like delayed CINV, appears linked to poor emetic control during previous chemotherapy treatments. In children, preschool and school age, the incidence of anticipatory CINV has been reported to range from $15 \%$ to $54 \%$, depending on research methods and antiemetic prophylaxis history (Foot and Hayes 1994; Tyc et al 1997) These data reinforce the importance of achieving excellent emetic control in children receiving chemotherapy.

The advent of 5-HT3 receptor antagonists has markedly improved patient lives. The different available agents have shown uniform advantages over older antiemetics. Of these medications, ondansetron has been extensively studied for prophylaxis against and treatment of CINV. Most papers that examine prophylactic ondansetron use in children examine early CINV in clinical reports. There are fewer than 10 randomized, controlled studies available in this age group and only 1 with a placebo-treated control group. The remainder of the studies reviewed compare ondansetron with phenothiazine derivatives. Because chemotherapy protocols (medications, dosing, and cycles) and antiemetic regimens (dosing, route, and frequency) vary with different cancers and

Table 2 Emetogenic potential of chemotherapy agents risk and (\%)

\begin{tabular}{|c|c|c|}
\hline \multirow[t]{2}{*}{ High risk (>90 \%) } & Carmustine $>250 \mathrm{mg} / \mathrm{m}^{2}$ Cisplatin $>50 \mathrm{mg} / \mathrm{m}^{2}$ & Lomustine $>60 \mathrm{mg} / \mathrm{m}^{2}$ Mechlorethamine Streptozocin \\
\hline & Cyclophosphamide $>1.5 \mathrm{~g} / \mathrm{m}^{2}$ Dacarbazine $>500 \mathrm{mg} / \mathrm{m}^{2}$ & \\
\hline \multirow[t]{3}{*}{ High risk (60-90\%) } & Carmustine $<250 \mathrm{mg} / \mathrm{m}^{2}$ Cisplatin & Dactinomycin $>1.5 \mathrm{mg} / \mathrm{m}^{2}$ Doxorubicin \\
\hline & $<50$ mg/m² Cyclophosphamide $0.75-1.5 \mathrm{~g} / \mathrm{m}^{2}$ & $>60 \mathrm{mg} / \mathrm{m}^{2}$ Mitoxantrone $>15 \mathrm{mg} / \mathrm{m}^{2}$ \\
\hline & Dacarbazine $<500 \mathrm{mg} / \mathrm{m}^{2}$ & Methotrexate $>1000 \mathrm{mg} / \mathrm{m}^{2}$ \\
\hline \multirow[t]{3}{*}{ High risk (30-60\%) } & Cyclophosphamide $<0.75 \mathrm{~g} / \mathrm{m}^{2}$ & Epirubicin $\leq 90 \mathrm{mg} / \mathrm{m}^{2}$ Idarubicin Ifosfamide \\
\hline & Dactinomycin $\leq 1.5 \mathrm{mg} / \mathrm{m}^{2}$ Daunorubicin & Methotrexate $0.25-1 \mathrm{~g} / \mathrm{m}^{2}$ \\
\hline & Doxorubicin $20-60 \mathrm{mg} / \mathrm{m}^{2}$ & \\
\hline \multirow[t]{2}{*}{ Moderate risk (10-30\%) } & Asparaginase Cytarabine $<1 \mathrm{~g} / \mathrm{m}^{2}$ & Etoposide Fluorouracil $<1 \mathrm{~g} / \mathrm{m}^{2}$ Methotrexate \\
\hline & Doxorubicin $<20 \mathrm{mg} / \mathrm{m}^{2}$ Docetaxel & $50-250 \mathrm{mg} / \mathrm{m}^{2}$ Mitomycin \\
\hline \multirow[t]{2}{*}{ Low risk $(<10 \%)$} & Bleomycin Busulfan Chlorambucil Fludarabine & Methotrexate $<50 \mathrm{mg} / \mathrm{m}^{2}$ Thioguanine \\
\hline & & Vinblastine Vincristine \\
\hline
\end{tabular}

Adapted from Hesketh et al (1997). 
treatment centers, comparison among studies is problematic. In addition, placebo-controlled trials performed solely in infants and preschool aged children are unavailable.

Keeping these limitations in mind, some data can be generalized for the use of 5-HT3 receptor antagonists in preventing and treating CINV. Children 18 months to 15 years of age receiving highly emetogenic agents have been described in a systematic review as having anywhere from $25 \%$ to $100 \%$ complete or major control of acute vomiting with ondansetron therapy (Antonarakis et al 2004). Holdsworth et al (1995) compared ondansetron treated and non-treated pediatric patients receiving carmustine, etoposide/cytarabine or cyclophosphamide and determined the NNT as 3 (CI 95\% $2-7)$. In a similar age group receiving high dose $(4.5 \mathrm{mg} / \mathrm{kg})$ ondansetron, Parker and colleagues (2001) found the NNT to prevent CINV from intrathecal methotrexate to be 2 .

In comparative trials with traditional antiemetics, ondansetron has been shown to have greater efficacy. In one study, children 18 months to 15 years of age receiving an intensification chemotherapy regimen for acute lymphocytic leukemia were randomized to receive either ondansetron $\left(3-5 \mathrm{mg} / \mathrm{m}^{2}\right)$ or metoclopramide plus dexamethasone and procyclidine. Complete or major control of vomiting was achieved in $93 \%$ and 33\% of children in each group, respectively (Dick et al 1995). In a similar study of children receiving emetogenic chemotherapy, Koseoglu and colleagues (1998) also demonstrated that ondansetron produced superior relief of symptoms. In randomized, controlled studies of 5-HT3 receptor antagonists, ondansetron appeared to be equivalent to granisetron but more effective than tropisetron (Stiakaki et al 1999; Jaing et al 2004). Granisetron has a longer duration of action, which offers advantages in terms of dosing schedules.

Studies of radiation-induced nausea vomiting in young children are limited. However, in combined studies with older children superior control of emesis, compared with phenothiazine derivatives, was demonstrated with ondansetron alone (Jurgens and McQuade 1992; Tramer et al 1998) and in combination with dexamethasone (Roberts and Priestman 1993; Kusnierczyk et al 2002).

\section{Gastroenteritis}

Gastroenteritis remains a major cause of morbidity and hospitalization in industrialized nations. In the United States, children younger than 5 years have 1 to 2 infections per year, resulting in 1.5 million medical consultations, and 200,000 hospitalizations (Pashar et al 1998). Hospitalizations are due to diarrhea and dehydration. Control of vomiting, in order to establish oral rehydration, can be important in counteracting these problems. However, in 1996 the American Academy of Pediatrics reported a consensus opinion that antiemetic medications were not indicated in children with gastroenteritis. They advised caution in prescribing these agents secondary to risk for adverse side-effects (Anonymous 1996).

Randomized, placebo-controlled trials have since demonstrated the efficacy and safety of ondansetron in the treatment of established nausea and vomiting associated with gastroenteritis. Reeves et al (2002) studied 107 children 3 months to 22 years of age (mean 5.5 years) and determined a NNT of 5.3 (NA) for cessation of vomiting and 6.25 to prevent hospital admission. In children 6 months to 12 years of age, Ramsook et al (2002) demonstrated a NNT of 4.5 (CI 95\% 1.2-5.4) for cessation of vomiting and of 8.3 to avoid administration of intravenous fluids. Although oral rehydration therapy remains the primary and essential focus, the Center of Disease Control and the American Academy of Pediatrics now recognize that ondansetron $100-150 \mu \mathrm{g} / \mathrm{kg}$ "can be effective in decreasing vomiting and limiting hospital admission" in gastroenteritis (Anonymous 2004; King et al 2003).

\section{Other causes of nausea and vomiting}

The incidence of opioid induced nausea and vomiting has been reported to range from $20 \%$ to $40 \%$ depending on medication and patient population (Campora et al 1991; Zun et al 2002). High dose ondansetron used in (8-16 mg orally or $1.5 \mathrm{mg} / \mathrm{kg}$ intravenously) has shown limited effectiveness in patients receiving neuraxial morphine, a mixture of oral opioid preparations, and morphine patient-controlled analgesia (PCA) with NNT of 3 (CI 95\% 2-11), 4.3 (NA), and 3 (CI 95\% 2-5), respectively (Alexander et al 1995; Sussman et al 1999; Tzeng et al 2003). In children, 2-10 years of age, receiving oral transmucosal fentanyl citrate with a PONV of $45 \%$, Binstock and colleagues (2004) were not able to demonstrate a significant antiemetic effect with ondansetron. Similarly, Munro et al (2002) found no response in children, 5-13 years of age, on morphine PCA.

Motion sickness is a common disorder related to confusion between sensory and cognitive functions. Motion sickness affects greater than $50 \%$ of children traveling in cars and planes. Symptoms tend to be most severe between 4 and 10 years of age (Setness and Van Beusekom 2004). Although there are no published studies examining the use of ondansetron for this disorder, motion sickness is commonly used as a predictor of PONV and CINV. A meta-analysis performed by 
Table 3 Guidelines for prophylactic therapy for children at risk for nausea and vomiting

\begin{tabular}{|c|c|c|c|}
\hline Risk category & PONV & CINVb,c & RINV \\
\hline High & $\begin{array}{l}\text { 5-HT3 rcpt Antagonists } \\
\text { plus corticosteroids plus } \\
\text { drug of another class }\end{array}$ & $\begin{array}{l}\text { 5-HT3 rcpt Antagonists plus } \\
\text { corticosteroids plus drug } \\
\text { of another class }^{d}\end{array}$ & $\begin{array}{l}\text { Corticosteroids plus } \\
5-\mathrm{HT} 3 \text { rcpt antagonists }\end{array}$ \\
\hline Moderate & $\begin{array}{l}\text { 5-HT3 rcpt Antagonists plus } \\
\text { corticosteroids or drug } \\
\text { of another class }\end{array}$ & $\begin{array}{l}\text { 5-HT3 rcpt Antagonists plus } \\
\text { corticosteroids or drug of } \\
\text { another class }\end{array}$ & $\begin{array}{l}\text { Corticosteroids or } 5-\mathrm{HT} 3 \\
\text { rcpt antagonists }\end{array}$ \\
\hline Low & No prophylaxis & $\begin{array}{l}\text { Corticosteroids or } \\
5-\mathrm{HT} 3 \text { rcpt antagonists }\end{array}$ & No prophylaxis \\
\hline
\end{tabular}

aGan et al (2003); 'D Dupuis and Nathan (2003); 'Aapro (2005).

Notes: Dopamine antagonists (metoclopramide, droperidol, and prochlorpromazine) or substance P/neurokinin I (NKI) receptor antagonist (aprepitant) pending pediatric studies.

Abbreviations: CINV, chemotherapy-induced nausea and vomiting; PONV, postoperative nausea and vomiting; rcpt, receptor; RINV, radiation-induced nausea and vomiting.

Figueredo and Canosa (1999) detected a NNT of 3.4 (CI 95\% 2.1-5.4) and 6.4 (NA) for prophylactic ondansetron (4 milligrams, intravenously) to prevent PONV in adult patients with a positive and negative history of motion sickness. This finding suggests a role for ondansetron in preventing and/or reducing the symptoms of motion sickness.

\section{Combination therapy}

Contemporary practice guidelines, based on extensive review of randomized control studies, for children at high risk for PONV and CINV recommend ondansetron in conjunction with other antiemetics (Culy et al 2001; Dupuis and Nathan 2003; Gan et al 2003). Combination therapy is superior to single-drug prophylaxis for PONV and CINV (Alvarez et al 1995; Habib et al 2001). Efficacy can be optimized by taking advantage of the different medications' mechanisms of action. In a particular, ondansetron in combination with corticosteroids has been shown to be the optimal treatment for PONV associated with tonsillectomies and highly emetogenic chemotherapy agents. Dosing regimes still need to be established but current literature contains the following recommendations for PONV: 150-500 $\mu \mathrm{g}$ (maximum of 10-12 $\mathrm{mg}$ ) for dexamethasone, $50-75 \mu \mathrm{g} / \mathrm{kg}$ (maximum of $1.25 \mathrm{mg}$ ) for droperidol, $500 \mu \mathrm{g} / \mathrm{kg}$ for dimenhydrinate and $70 \mu \mathrm{g} / \mathrm{kg}$ for perphenazine (Gan et al 2003). The dose of ondansetron doses (100-150 $\mu \mathrm{g} / \mathrm{kg}$ ) may be reduced when used in combination with another antiemetic (Tramer 2001). Triple combination regiments are recommended for patients at high risk for PONV and CINV. Dosing for antiemetic prophylaxis for CINV include ondansetron 3-5 $\mathrm{mg} / \mathrm{m}^{2}$ and dexamethasone $8-16 \mathrm{mg} / \mathrm{m}^{2}$ (Curly et al 2001). Guidelines for prophylactic therapy for children at risk for nausea and vomiting, based on available data from randomized controlled studies and expert consensus, are summarized in Table 3.

\section{Conclusions}

Ondansetron has shown good efficacy in the prevention and treatment of nausea and vomiting in young children with exposure to emetogenic agents, which include anesthetic agents, oncologic therapeutics, or viral infections. In children undergoing surgery associated with a high risk of PONV, ondansetron demonstrated superior prophylactic antiemetic efficacy compared with placebo, droperidol, and metoclopramide. It has been demonstrated that ondansetron is relatively free of adverse events. When combined with dexamethasone, ondansetron has been shown to establish almost complete control of emesis. Depending on risk factors for nausea and vomiting, ondansetron, alone or in combination, is the treatment of choice for young children undergoing surgery and chemotherapy.

\section{References}

Aapro M. 2005. 5-HT(3)-receptor antagonists in the management of nausea and vomiting in cancer and cancer treatment. Oncology, 69:97-109.

Alexander R, Lovell AT, Seingry D, et al. 1995. Comparison of ondansetron and droperidol in reducing postoperative nausea and vomiting associated with patient-controlled analgesia. Anaesthesia, 50:1086-8.

Alvarez O, Freeman A, Bedros A, et al. 1995. A double-blind crossover ondansetron-dexamethasone versus ondansetron-placebo study for the treatment of chemotherapy-induced nausea and vomiting in pediatric patients with malignancies. J Pediatr Hematol Oncol, 17:145-50.

Andrews PL, Hawthorn J. 1988. The neurophysiology of vomiting. Res Clin Gastroenterol, 2:141-68.

Anonymous. 1987. 5-HT3 receptor antagonists: a new class of antiemetics. Lancet, 1(8548):1470-1.

Anonymous. 1996. Practice parameter: the management of acute gastroenteritis in young children. American Academy of Pediatrics, Provisional Committee on Quality Improvement, Subcommittee on Acute Gastroenteritis. Pediatrics, 97:424-35.

Anonymous. 2004. Managing acute gastroenteritis among children: oral rehydration, maintenance, and nutritional therapy. Pediatrics, 114: 507.

Antonarakis ES, Evans JL, Heard GF, et al. 2004. Prophylaxis of acute chemotherapy-induced nausea and vomiting in children with cancer: what is the evidence? Pediatr Blood Cancer, 43:651-8. 
Binstock WI, Rubin R, Bachman C, et al. 2004. The effect of premedication with OTFC, with or without ondansetron, on postoperative agitation, and nausea and vomiting in pediatric ambulatory patients Paediatr Anaesth, 14:759-67.

Campora E, Merlini L, Pace M, et al. 1991. The incidence of narcoticinduced emesis. J Pain Symptom Manage, 6:428-30.

Coates A, Abraham S, Kaye SB, et al. 1983. On the receiving end: patients' perception of cancer chemotherapy. Eur J Cancer Clin Oncol, 19:203-8.

Cohen MM, Cameron CB, Duncan PG. 1990. Pediatric anesthesia morbidity and mortality in the perioperative period. Anesth Analg, 70:160-7.

Culy CR, Bhana N, Plosker GL. 2001. Ondansetron: a review of its use as an antiemetic in children. Pediatric Drugs, 3:441-479.

Dick GS, Meller ST, Pinkerton CR. 1995. Randomised comparison of ondansetron and metoclopramide plus dexamethasone for chemotherapy induced emesis. Arch Dis Child, 73:243-5.

Domino KB, Anderson EA, Polissar NL, et al. 1999. Comparative efficacy and safety of ondansetron, droperidol, and metoclopramide for preventing postoperative nausea and vomiting: a meta-analysis. Anesth Analg, 88:1370-9.

Dupuis LL, Nathan PC. 2003. Options for the prevention and management of acute chemotherapy-induced nausea and vomiting in children. Pediatric Drugs. 5:597-613.

Eberhart LH, Morin AM, Wulf H, et al. 2002. Patient preferences for immediate postoperative recovery. Br J Anaesth, 89:760-1.

Figueredo E, Canosa L. 1999. Prophylactic ondansetron for post-operative emesis: meta-analysis of its effectiveness in patients with and without a previous history of motion sickness. Eur J Anaesthesiol, 16:556-64.

Foot ABM, Hayes C. 1994. Audit of guidelines for effective control of chemotherapy and radiotherapy induced emesis. Arch Dis Child, 71:475-80.

Gan TJ. 2005. Selective serotonin 5-HT3 receptor antagonists for postoperative nausea and vomiting: are they all the same? CNS Drugs, 19:225-38.

Gan TJ, Meyer T, Apfel CC, et al. 2003. Consensus guidelines for managing postoperative nausea and vomiting. Anesth Analg, 97:62-71.

Gold BS, Kitz DS, Lecky JH, et al. 1989. Unanticipated admission to the hospital following ambulatory surgery. JAMA, 262:3008-10.

Goodin S, Cunningham R. 2002. 5-HT(3)-receptor antagonists for the treatment of nausea and vomiting: a reappraisal of their side-effect profile. Oncologist, 7:424-36.

Green JA, Watkin SW, Hammond P, et al. 1989. The efficacy and safety of GR38032F in the prophylaxis of ifosfamide-induced nausea and vomiting. Cancer Chemother Pharmacol, 24:137-40.

Habib AS, Gan TJ. 2001. Combination therapy for postoperative nausea and vomiting: a more effective prophylaxis? Amb Surg, 9:59-71.

Henzi I, Walder B, Tramer MR. 1999. Metoclopramide in the prevention of postoperative nausea and vomiting: a quantitative systematic review of randomized, placebo-controlled studies. Br J Anaesth, 83:761-71.

Henzi I, Walder B, Tramer MR. 2000. Dexamethasone for the prevention of postoperative nausea and vomiting: a quantitative systematic review. Anesth Analg, 90:186-94.

Hesketh PJ, Kris MG, Grunberg SM, et al. 1997. Proposal for classifying the acute emetogenicity of cancer chemotherapy. J Clin Oncol, 15:103-9.

Hirayama T, Ishii F, Yago K, et al. 2001. Evaluation of the effective drugs for the prevention of nausea and vomiting induced by morphine used for postoperative pain: a quantitative systematic review. Yakugaku Zasshi, 121:179-85.

Holdsworth MT, Raisch DW, Duncan MH, et al.1995. Assessment of chemotherapy-induced emesis and evaluation of a reduced-dose intravenous ondansetron regimen in pediatric outpatients with leukemia. Ann Pharmacother, 29:16-21.

Holdsworth MT, Raisch DW, Frost J. 2006. Acute and delayed nausea and emesis control in pediatric oncology patients. Cancer, 106:931-40.
Iacono G, Merolla R, D’Amico D, et al. 2005. Gastrointestinal symptoms in infancy: a population-based prospective study. Dig Liver Dis, 37:432-8.

Jaing T-H, Tsay P-K, Hung I-J, et al. 2004. Single-dose oral granisetron versus multidose intravenous ondansetron for moderately emetogenic cyclophosphamide-based in pediatric outpatients with acute lymphoblastic leukemia. Pediatr Hematol Oncol, 21:227-35.

Jurgens H, McQuade B. 1992. Ondansetron as prophylaxis for chemotherapy and radiotherapy-induced emesis in children. Oncology, 49:279-85.

Khalil SN, Roth AG, Cohen IT, et al. 2005. A double-blind comparison of intravenous ondansetron and placebo for preventing postoperative emesis in 1- to 24-month-old pediatric patients after surgery under general anesthesia. Anesth Analg, 101:356-61.

King CK, Glass R, Bresee JS, et al. 2003. Centers for disease control and prevention. Managing acute gastroenteritis among children: oral rehydration, maintenance, and nutritional therapy. MMWR Recomm Rep, 52:1-16.

Koseoglu V, Kurekci AE, Sarici U, et al. 1998. Comparison of the efficacy and side-effects of ondansetron and metoclopramide-diphenhydramine administered to control nausea and vomiting in children treated with antineoplastic chemotherapy: a prospective randomized study. Eur J Pediatr, 157:806-10.

Kovac AL, O'Connor TA, et al. 1999. Efficacy of repeat intravenous dosing of ondansetron in controlling postoperative nausea and vomiting: a randomized, double-blind, placebo-controlled multicenter trial. J Clin Anesth, 11:453-9.

Kusnierczyk NM, Saunders EF, Dupuis LL. 2002. Outcomes of antiemetic prophylaxis in children undergoing bone marrow transplantation. Bone Marrow Transplant, 30:119-24.

Lee A, Gin T, Lau AS, et al. 2005. A comparison of patients' and health care professionals' preferences for symptoms during immediate postoperative recovery and the management of postoperative nausea and vomiting. Anesth Analg, 100:87-93.

Leeser J, Lip H. 1991. Prevention of postoperative nausea and vomiting using ondansetron, a new, selective, 5-HT3 receptor antagonist. Anesth Analg, 72:751-5.

Lerman J. 1992. Surgical and patient factors involved in postoperative nausea and vomiting. BrJ Anaesth, 69:24S-32.

Litman RS, Wu CL, Catanzaro FA. 1994. Ondansetron decreases emesis after tonsillectomy in children. Anesth Analg, 78:478-81.

Mercadante S, Sapio M, Serretta R. 1998. Ondansetron in nausea and vomiting induced by spinal morphine. J Pain Symptom Manage, 16:259-62.

Munro FJ, Fisher S, Dickson U, et al. 2002. The addition of antiemetics to the morphine solution in patient controlled analgesia syringes used by children after an appendicectomy does not reduce the incidence of postoperative nausea and vomiting. Paediatr Anaesth, 12:600-3.

Panda NB, Bharadwaj N, Kapoor P, et al. 2004. Prevention of nausea and vomiting after middle ear surgery: combination of ondansetron and dexamethasone is the right choice. $J$ Otolaryngol, 33:88-92.

Pashar UD, Holman RC, Bresee JS, et al. 1998. Epidemiology of diarrheal disease among children in four West Coast health maintenance organizations. Pediatr Infect Dis $J, 17: 605-11$.

Parker RI, Prakash D, Mahan RA, et al. 2001. Randomized, double-blind, crossover, placebo-controlled trial of intravenous ondansetron for the prevention of intrathecal chemotherapy-induced vomiting in children. J Pediatr Hematol Oncol, 23:578-81.

Patel RI, Hannallah RS. 1988. Anesthetic complications following pediatric ambulatory surgery: a 3-year study. Anesthesiology, 69:1009-12.

Pisters KM, Kris MG. 1998. Treatment-related nausea and vomiting. In: Berger A, Portenoy RK, Weissman DE (eds). Principles and practice of supportive oncology. Philadelphia, PA: Lippincott-Raven Publishers.

Pitkanen MT, Numminen MK, Tuominen MK, et al. 1997.Comparison of metoclopramide and ondansetron for the prevention of nausea and vomiting after intrathecal morphine. Eur J Anaesthesiol, 14:172-7. 
Ramsook C, Sahagun-Carreon I, Kozinetz CA, et al. 2002. A randomized clinical trial comparing oral ondansetron with placebo in children with vomiting from acute gastroenteritis. Ann Emerg Med, 39:397-403.

Reeves JJ, Shannon MW, Fleisher GR. 2002. Ondansetron decreases vomiting associated with acute gastroenteritis: a randomized, controlled trial. Pediatrics, 109:62.

Roberts JT, Priestman TJ. 1993. A review of ondansetron in the management of radiotherapy-induced emesis. Oncology, 50:173-9.

Sanchez-Ledesma MJ, Lopez-Olaondo L, Pueyo FJ, et al. 2002. A comparison of three antiemetic combinations for the prevention of postoperative nausea and vomiting. Anesth Analg, 95:1590-5.

Schnell FM. 2003. Chemotherapy-induced nausea and vomiting: the importance of acute antiemetic control. Oncologist, 8:187-98.

Setness PA, Van Beusekom M. 2004. Patient Notes: motion sickness. Postgrad Med, 116:64.

Splinter W, Roberts DJ. 1997. Prophylaxis for vomiting by children after tonsillectomy: dexamethasone versus perphenazine. Anesth Analg, 85:534-7.

Steward DL, Welge JA, Myer CM. 2003. Steroids for improving recovery following tonsillectomy in children. Cochrane Database Syst Rev, 1:CD003997.

Stiakaki E, Savvas S, Lydaki E, et al. 1999. Ondansetron and tropisetron in the control of nausea and vomiting in children receiving combined cancer chemotherapy. Pediatr Hematol Oncol, 16:101-8.

Sussman G, Shurman J, Creed MR, et al. 1999. Intravenous ondansetron for the control of opioid-induced nausea and vomiting. International S3AA3013 Study Group. Clin Ther, 21:1216-27.

Tramer MR. 2001. A rational approach to the control of postoperative nausea and vomiting: evidence from systemic reviews. II. Recommendations for prevention and treatment and research agenda. Acta Anaesthesiol Scand, 45:14-19.
Tramer MR, Reynolds DJ, Moore RA, et al. 1997. Efficacy, dose-response, and safety of ondansetron in prevention of postoperative nausea and vomiting: a quantitative systematic review of randomized placebocontrolled trials. Anesthesiology, 87:1277-89.

Tramer MR, Reynolds DJ, Stoner NS, et al. 1998. Efficacy of 5-HT3 receptor antagonists in radiotherapy-induced nausea and vomiting: a quantitative systematic review. Eur J Cancer, 34:1836-44.

Tramer MR, Walder B. 1999 Efficacy and adverse effects of prophylactic antiemetics during patient-controlled analgesia therapy: a quantitative systematic review. Anesth Analg, 88:1354-61.

Tyc VL, Mulhern RK, Bierberich AA. 1997. Anticipatory nausea and vomiting in pediatric cancer patients: an analysis of conditioning and coping variables. J Dev Behav Pediatr, 18:27-33.

Tzeng JI, Chu KS, Ho ST, et al. 2003. Prophylactic iv ondansetron reduces nausea, vomiting and pruritus following epidural morphine for postoperative pain control. Can J Anaesth, 50:1023-6.

Watcha MF, White PF. 1992. Postoperative nausea and vomiting: its etiology, treatment, and prevention. Anesthesiology, 77:162-84.

White LA, Vanarase M, Brockbank K, et al. Patient-controlled analgesia and postoperative nausea and vomiting: efficacy of a continuous infusion of ondansetron. Anaesth, 56:365-9.

Wisselo TL, Stuart C, Muris P. 2004. Providing parents with information before anaesthesia: what do they really want to know? Paediatr Anaesth, 14:299-307.

Zun LS, Downey LV, Gossman W, et al. 2002. Differences in narcoticinduced emesis in the ED. Am J Emerg Med, 20:151-4. 
